\title{
4
}

\section{Real World Learning Through Civic Engagement: Principles, Pedagogies and Practices}

\section{Kristine Mason O'Connor and Lindsey McEwen}

\section{Introducing Real World Learning Through Civic Engagement}

In times of unprecedented change and uncertainty, real world learning through civic engagement enables students to thrive as empowered critical thinkers and actors developing skills, confidence and capabilities for life, employment and citizenship. Real world learning through civic engagement builds university capacity to collaborate equitably with communities to strengthen and enhance social capital and address emerging societal and environmental challenges, locally and globally. This chapter presents developments in curriculum-based civic engagement and considers drivers, pedagogies, principles and examples of practice as

\footnotetext{
K. Mason O'Connor $(\bowtie)$

University of Gloucestershire, Cheltenham, UK

e-mail:kmoconnor@glos.ac.uk

L. McEwen

University of the West of England, Bristol, UK 
indicated in the concept map (Fig. 4.1). The chapter concludes with proposals to implement this transformational mode of learning.

The "definitional anarchy of civic engagement" (Sandmann, 2008, p. 91) succinctly captures the multiple diverse practices whereby universities establish real world learning opportunities with communities. Collectively such practices can be viewed through the lens of the scholarship of engagement, "connecting the rich resources of the university to our most pressing social, civic, and ethical problems ... Campuses would be viewed by both students and professors not as isolated islands, but as staging grounds for action" (Boyer, 1996, p. 20).

More than twenty years after Boyer's call to action, the nature of the 'problem contexts' to community-based learning (CBL) has shifted away from a safer core of issues towards dealing with more challenging local problems, where student engagement involves risk taking but also strong potential for Fink's 'significant learning'. For example, the 'integration' element of Fink's taxonomy of significant learning refers to connecting "ideas, people and realms of life" (2003, p. 30). "The act of making new connections gives learners a new form of power especially intellectual power" (ibid., p. 31).
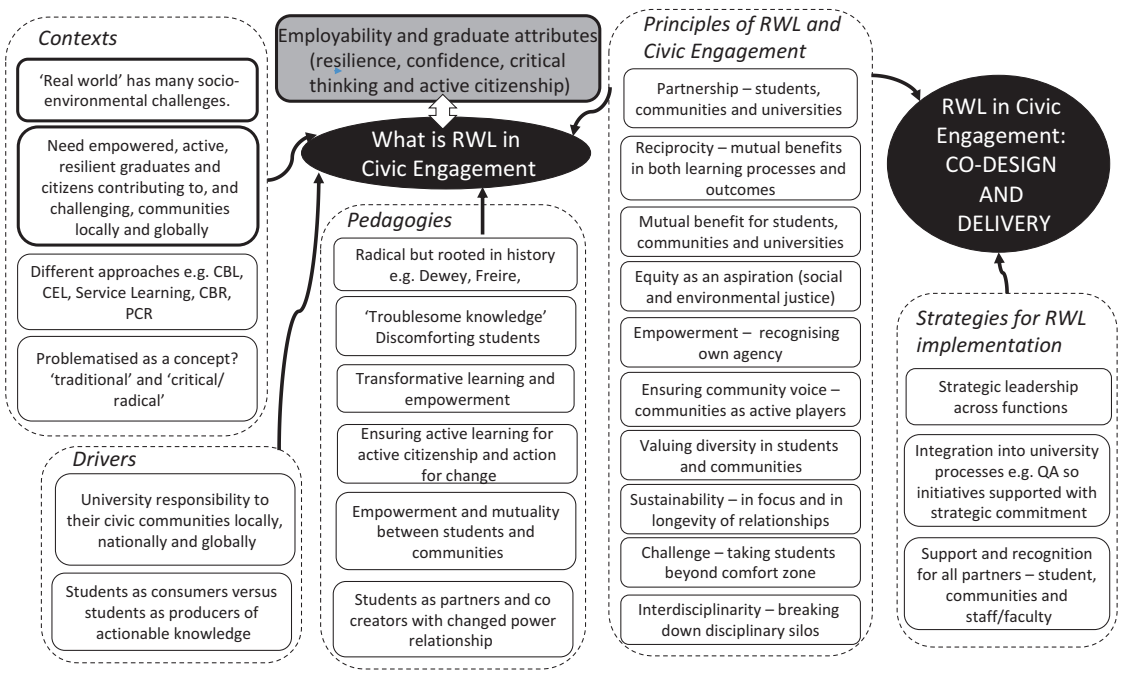

Fig. 4.1 Real world learning (RWL) through civic engagement concept map 
Greater attention is now being addressed to critical parameters in community-based learning, such as how local problems are identified, the role of and benefits to students and communities, and pithy ethical issues that relate to such matters as equity, diversity and relative affluence. In the shift to this new paradigm of real world civic engagement, there is plentiful opportunity to gain insights and develop principles across a wide range of learning and experiences.

\section{Missions, Manifestos and Declarations}

Civic engagement is hardly a recent concept for universities. As Watson and others have observed, most university foundations expressed commitment to an element of service to their communities in their stated purpose and mission (Watson, Hollister, Stroud, \& Babcock, 2011). This was certainly the case in the USA where service learning was rooted in the foundations of the Land Grant Colleges in the mid-nineteenth century. In differing forms, civic engagement through the curriculum has continued to thrive in the USA with over 360 "campuses with the elective [Carnegie] Community Engagement Classification" in 2018 (Brown, n.d.). In the UK, by contrast, for several decades, founders' commitments gathered dust in many a university archive whilst institutions focused on research, teaching and income-generating activities. This neglect is explained by Goddard and Kempton,

In the UK 19th century institutions that were the predecessors of the socalled 'red brick' universities evolved to meet the needs of a rapidly evolving industrial society ... These institutions depended to a large degree on local public support. During the 20th century these local links weakened with increasing central government support and influence over local government [and] the nationalisation of higher education ... As a consequence many civic institutions turned their backs on their host cities. However in the 21 st century some of these are seeking to reinvent themselves as civic institutions... (Goddard \& Kempton, n.d.) 
By 2018, over eighty UK institutions had signed up to the UK National Co-ordinating Centre for Public Engagement (NCCPE) Manifesto for Public Engagement, representing approximately half of all UK higher education institutions, and by the following year more than fifty universities had "reaffirmed their commitment to their local communities by pledging to put the economy and quality of life in their home towns and cities at the top of their list of priorities" (our emphasis) (Brabner, 2019).

Internationally, the past twenty years have witnessed a burgeoning of universities committing to civic engagement. In 1999, the Global University Network for Innovation (GUNI) was established. Its mission is "to strengthen the role of higher education in society contributing to the renewal of the visions and policies of higher education across the world under a vision of public service, relevance and social responsibility" (GUNI, 2013, p. 2). In 2019, it comprised 227 members across 80 countries. The Tufts Talloires Network was founded in 2005, comprising heads of universities from twenty-three countries who signed the Talloires Declaration on the civic roles and social responsibilities of higher education:

We are dedicated to strengthening the civic role and social responsibility of our institutions ... Through learning, values and commitment of faculty, staff and students, our institutions create social capital, preparing students to contribute positively to local, national and global communities. (Talloires Network, 2005)

Ten years later, over 300 university leaders from 70 countries had signed the Declaration. In 2018, Talloires' partner national and regional networks included AsiaEngage; CLAYSS: The Latin American Centre for Service Learning; Engagement Australia; and SAHECEF: South African Higher Education Community Engaged Forum. 


\section{Drivers for Change: Austerity to Posterity}

Beginning with a focus on the UK, we present key drivers and imperatives for developing university civic engagement. A policy of government public austerity measures in the UK over the past decade led to funding for universities being significantly reduced. Austerity prompted calls for all publicly funded institutions, including universities, to account for themselves in terms of their societal value. Furthermore, with many being sizeable charities enjoying certain tax advantages, universities are required to be transparent in demonstrating social responsibility.

A related economic policy was the introduction of, and a hefty increase in, student fees. This, together with the annual National Student Survey rankings, promoted cultures of 'customer focus' or 'value for money'. One response has been for universities to fast-track graduate employability measures, with civic engagement activity shown to add value to the development of students' employability skills and capabilities (Mason O’Connor, Lynch, \& Owen, 2011). Providing learning opportunities beyond lectures and seminars was spurred on by the introduction of the Teaching Excellence Framework (TEF) in 2017 which assesses how institutions "ensure excellent outcomes for their students in terms of graduatelevel employment or further study", as well as what they are doing "in addition" (our emphasis) to meeting national quality standards and awards (Office for Students, 2019).

According to an NCCPE report in 2015, whilst most universities had developed an engagement strategy, it had not been fully implemented. There was "much more evidence of more traditional 'inspirational' engagement, rather than two-way exchange" (Hill, 2015, p. 6). Festivals of ideas would be an example where experts from the university enthuse and enthral audiences with presentations and demonstrations. Over the ensuing five years, universities have developed a wider range of engagement activities, from comedy clubs to supporting vulnerable community members with technical solutions. However, this growth in 'public engagement' activity is not matched by growth in strategic civic engagement through the curriculum, which remains an activity largely promoted by enthusiasts. A similar point was made in Lord Kerslake's 
foreword to the 2019 UPP Foundation Civic University Independent Commission Report, whilst there was "much enthusiasm for the civic role and many excellent individual initiatives ... we found few examples of a systematic and strategic approach to the civic role based on an analysis of the needs of the place" (Kerslake, 2019, p. 5).

The international imperative for sustainable development has been another key driver for higher education, with some HEIs explicitly aligning themselves in 'whole-institution approaches' (see UNESCO, 2018, p. 45). Furthermore the United Nations Educational, Scientific and Cultural Organization (UNESCO, 2014, 2018) emphasises the importance of Education for Sustainable Development (ESD) or Learning for Sustainability (LfS), and the delivery of seventeen Sustainable Development Goals (SDGs) that aspire "to end poverty, protect the planet and ensure prosperity for all" by 2030. ESD proposes important links between local and global citizenship and the need for active citizenship, with implications for citizenship education at all educational levels. UNESCO $(2018$, p. 82) specifically advocates service learning as one approach "to facilitate learning about global justice and reduction of poverty" (SDG1 'No poverty') by planning and implementing "local servicelearning and/or engagement opportunities for empowering poor people, reducing their vulnerability to different hazards and increasing their resilience...".

These goals apply domestically as well as internationally in relation to the roles of active citizens (see UK HM Government's 2018 Civil Society Strategy: Building a future that works for everyone) although the role of higher education in building social responsibility is not discussed. However, the GuildHE/NUS (2016) report Active Citizenship: The role of higher education and its Charter for Active Citizenship cite the UNESCO, 2009 World Conference on Higher Education (2016, p. 7):

Higher education institutions, through their core functions (research, teaching and service to the community) carried out in the context of institutional autonomy and academic freedom, should increase their interdisciplinary focus and promote critical thinking and active citizenship. This would contribute to sustainable development, peace, well-being and the realization of human rights, including gender equity. 


\section{Pedagogies of Empowerment and Transformation}

Student learning through community engagement is rooted in problembased, reflective, 'deep learning' pedagogies of empowerment, transformation, critical thinking and social participation (Dewey, 1938; Freire, 1970; Kolb, 1984; Marton and Säljö 1976; Wenger, 1999; Mezirow, 2000, in Mason O’Connor, Lynch, \& Owen, 2011, p. 106).

These pedagogies of real world learning fly in the face of students as 'customers', not only in their propensity for transformation, but in their potential to unsettle and disturb, challenging taken-for-granted beliefs about the 'real world'. The experience can be "troublesome", being conceptually difficult or "alien" (Perkins, 1999). Students may even experience "the ambivalence, anger and frustration that can accompany genuine learning” (Delucchi \& Smith, 1997, p. 337). Customers certainly don't want to be troubled.

The proposition of knowledge being constructed can be traced to Dewey in the early twentieth century for whom learning necessitated acquiring and reflecting on experience; knowledge is not 'out there' to be consumed.

The academic subjects often sort, categorize, and present lists of facts and answers in text books, but this is not how facts originally emerged. [Dewey] reminds us, instead, facts emerged from real world people trying to solve real problems. (Fallace, 2016, p. 186)

Similarly, Freire's radical pedagogy of real world learning contests the idea of the teacher depositing or 'banking' knowledge in the learner, "the more students work at storing the deposits entrusted to them, the less they develop the critical consciousness which would result from their interaction in the world as transformers of that world" (Freire, 2005, p. 73). By advocating instead 'problem-posing education', Freire opens the way for transformational knowledge to be created. Here real world learning where students engage with others in the civic sphere to address practical problems resonates with Meyer and Land's (2005) work on 
threshold concepts in its potential to be 'transformative', 'irreversible' and 'integrated'.

Drawing on, amongst others, the work of Dewey and Freire, Mezirow $(1978,1991,2000,2003)$ developed the concept of transformative learning, defined as "learning that transforms problematic frames of reference-sets of fixed assumptions and expectations (habits of mind, meaning perspectives, mindsets) — to make them more inclusive, discriminating, open, reflective, and emotionally able to change" (Mezirow, 2003, p. 58).

Transformative learning emphasises the role of student, teacher as facilitator and the setting for learning as being out of an individual's comfort zone and, particularly, the importance of expansion of the consciousness, change in basic world view and empowerment (McEwen, Strachan, \& Lynch, 2011).

These pedagogies of real world learning connect with Gibbons' concept of Mode 2 knowledge which is

produced in a context of application involving a much broader range of perspectives [than Mode 1]. Mode 2 is transdisciplinary not only drawing on disciplinary contributions but can set up new frameworks beyond them; it is characterised by heterogeneity of skills, by a preference for flatter hierarchies and organisational structures which are transient. It is more socially accountable and reflexive than Mode 1. (Gibbons, 2000, p. 159)

Interdisciplinarity is a key pedagogic feature of real world learning through civic engagement. Here again one is reminded of Dewey who "believed that the unity of experience artificially severed by academic subjects needed to be restored" (Fallace, 2016, p. 186); it is pertinent to note that the 2014 UK Research Excellence Framework (REF) exercise commented that "wider impacts and benefits often stem from multidisciplinary work" (UKRI, n.d.).

There is now much greater attention to wider critical national and international agendas that connect local and global, including the need for climate resilience, imperatives of learning for sustainability (UNESCO, 2018) and 'glocal' citizenship and within this, the role of citizens in such issues as place-making and local governance. This has given a new lens 
with which to view university civic engagement involving a 'move' from the traditional disciplines involved in service learning (e.g. education and health) to a much wider set of disciplines that span the gamut of science (STEM), social science and arts and humanities (e.g. see El-Gabry, 2018; Kramer \& Fask, 2017). In his introduction to the 2017 report on the social responsibility of universities, Peter Wells, head of higher education for UNESCO, wrote:

The role of higher education institutions in developing the critical thinking needed in young minds and researchers to find solutions to the problems facing our world can no longer be taken in isolation, but must be approached in ways that cross institutional and disciplinary boundaries. (Wells, 2017, p. 29)

Education for Sustainable Development (UNESCO, 2018) draws on pedagogies that are participatory, learner-centred, action-orientated and transformative. UNESCO cites such collaborative real world learning practices, with service-learning projects on sustainability being one learning context, in which learners take collaborative action. This links to the emergent concept of transgressive learning promoted by Lotz-Sisitka, Wals, Kronlid, and McGarry (2015) — that is, learning "to overcome the status quo and prepare the learner for disruptive thinking and the cocreation of new knowledge" (UNESCO, 2018, p. 49).

Alongside, there is increasing interest in citizenship education or pedagogies for active citizenship, and relationships between learning and action. There is longer-standing attention to citizenship education within student learning and achievement in secondary education compared with higher education (see Crick Report-Advisory Group on Citizenship, 1998; Weinberg \& Flinders, 2018). Wasner (2016) explicitly identifies 'critical service learning' as a participatory pedagogical approach to global citizenship and international mindedness, while Wood, Taylor, Atkins, and Johnston (2018) emphasise the importance of learning through affective and cognitive domains for deeper democratic engagement. Although there is less explicitly on imperatives for active citizen participation through higher education, the Guild HE/National Union of Students (2016) report Active Citizenship: The role of higher education highlights 
service learning as one means to deliver citizen education, with emphasis on research with the community.

\section{What's in a Name? Modes of Real World Learning Through Civic Engagement}

In our review of approaches to university-community engagement through the curriculum, we presented a range of modes (Mason O'Connor, McEwen, Owen, Lynch, \& Hill, 2011). It would be tempting to try to develop this work by constructing a continuum of practices with the emphasis on student learning at one end (e.g. service learning) and community learning the other (e.g. community-based engaged research). However, this would be disingenuous. Take for example practices named service learning. With its origins in 'volunteering', a criticism levelled at service learning is its inherent power imbalance, and whilst studies show benefit to student learning, the benefit to communities is underresearched (Blouin \& Perry, 2009). Stoecker (2016) argues that too frequently service learning prioritises students' learning interests over those of the community. However, this is contested by Asghar and Rowe's (2017) work on service learning within health care: "reciprocal relationships which challenge established ideas and practices, together with engaging students in critical informed analysis are key components in ensuring service learning is socially just" (2017, p. 117).

Furthermore, Mitchell (2008) proposes that service learning is not unidimensional. She distinguishes between two forms of service learning: 'traditional service learning' and 'critical service learning' differentiated in relation to their ability to either perpetuate or change the status quo. Critical service learning also focuses on social justice with the ultimate aim being to "deconstruct systems of power so the need for service and the inequalities that create and sustain them are dismantled" (Mitchell, 2008, p. 50).

These pedagogies link to wider moves to 'radical' civic engagement in some institutions with critics of service learning arguing that the modes of engagement practice which we refer to later represent significantly 
more than mere changed nomenclature; rather, they represent a paradigm shift, focusing on action for change and co-production of knowledge, moving the focus from service towards equitable collaborative partnership between students, faculty and communities.

Boland portrays a defining feature of community-based learning as being:

its explicit focus where the design and enactment of the curriculum are underpinned with a rationale which invokes - to varying extents-concepts such as active citizenship, democracy, social justice, community and civic engagement, while simultaneously advancing the goal of student learning. (Boland, 2014, p. 181)

Community-based research (CBR) expresses the growing prominence in undergraduate education to forge links between research and teaching. Engaging undergraduates as researchers enables them to "grow in confidence as they approach the demanding complexities of knowing and acting in the modern world" (Fung, 2016, p. 37). Furthermore, CBR can enable students to engage in "varying and multiple modes of generating knowledge" (Tandon, Hall, Lepore, \& Singh, 2016, p. 14). "Thinking, knowing, feeling about a particular subject (manifested in the forms of arts, music, theatre, roles plays, photovoices etc.) needs to be promoted as equally effective methods as cognitive methods" (ibid.).

Community-based participatory research (CBPR) "begins with a research topic of importance to the community and has the aim of combining knowledge with action and achieving social change" (O'Mahoney, Burns, \& McDonell, n.d.). Community-based engaged research "is conducted by, for and/or with the participation of the community members: an emergent paradigm of really useful research for the Twenty-first Century" (Hall, Lall, \& Heng Chan, n.d.).

From their experience and research in the USA, Brabant and Braid (2009, p. 61) concluded, "there is no definition of civic engagement that fits all institutions, although there may be similar forces driving universities and colleges to assume a greater role in maintaining the economic, social and political health of their respective communities." 
In our previous review we concluded that "this lack of definition can be considered a strength rather than a limitation, engendering local debate as to what these terms might mean in different contexts" (Mason O’Connor, McEwen, et al., 2011, p. 4).

\section{Acting on Principles: Civic Engagement Through the Curriculum}

Given there is no specific optimal mode or method of university civic engagement for universities and communities to adopt, we propose a set of key principles to serve as a lens to inform these debates; these principles are based on our exploration of literature and reflections on practice. In so doing we share the view about community-engaged research being characterised not by method or approach but by the principles which guide it. The principles we have identified are partnership, reciprocity, mutual benefit, equity (social justice), empowerment, ensuring community voice, valuing diversity, sustainability, challenge and interdisciplinarity. These are presented as axes on the spidergram in Fig. 4.2. This format was chosen, first, to emphasise that there is not a hierarchy of principles and, second, for its potential as a tool for self-evaluation and quality improvement, such as profiling development of a civic engagement project over time. It can be used to highlight which principles are being practised most powerfully, as well as those requiring further development. (Dotted line gives an example.)

These principles link to those for ESD (e.g. interdisciplinarity and empowerment) and citizenship education (e.g. valuing diversity and equity). Examples of the principles playing out in practice feature in a number of international initiatives (Table 4.1).

The four case studies (Table 4.2) presented in Chap. 5 illustrate different approaches, scales and institutional contexts to civic engagement, specific to meeting their particular objectives. As we consider below, they vividly exemplify principles of real world learning through civic engagement being put into practice.

Each of the case studies demonstrates principles of establishing effective partnerships for sustainability. In Solent University's Community 


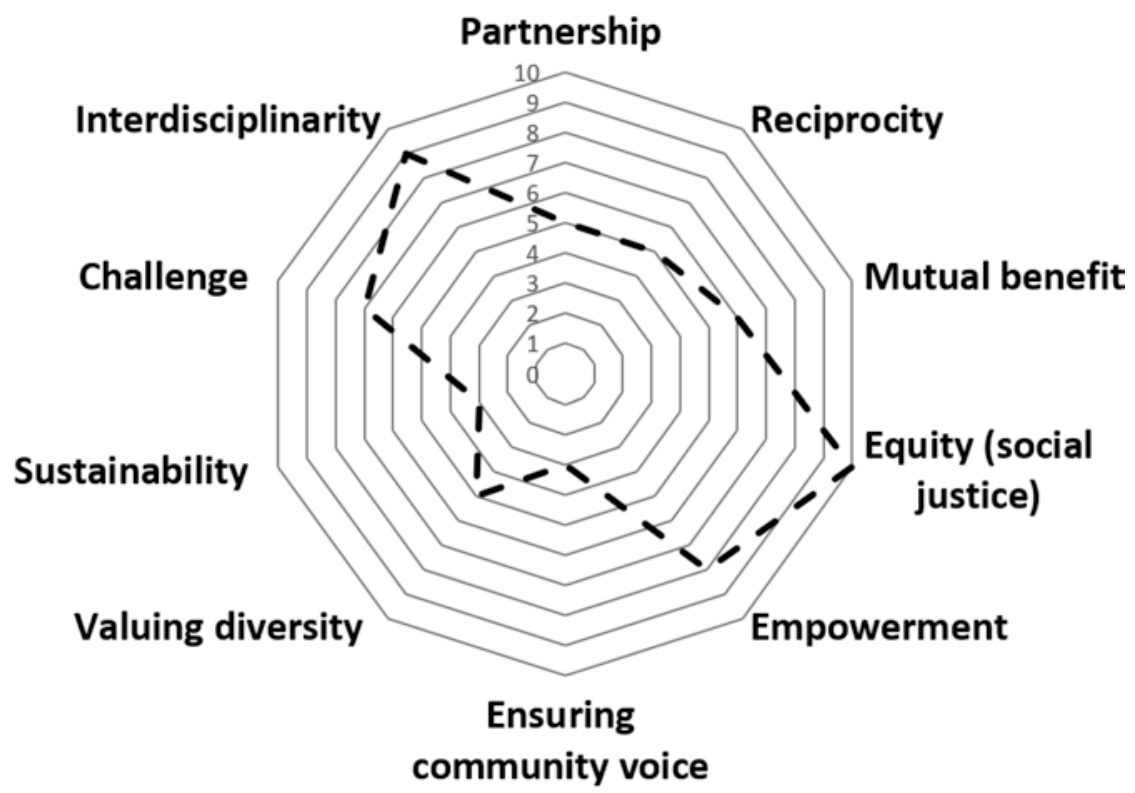

Fig. 4.2 Ten principles of real world learning through civic engagement

Innovation Programme, 'Healthy Living Project', a three-way partnership, is created, nurtured and developed between students, health practitioner and women from diverse ethnic minorities. The International Practicum Pilot, 'Limerick Inside Out', highlights, "The deliberate shift in focus from 'depth' to 'breadth' of community engaged learning ... supplemented by the establishment of a strategic partnership with the Limerick City and County Council" (Gleeson, Mey and Warren-Perkinson).

Principles of challenge and valuing diversity are evident across the case studies with the 'Solent Football Leadership Programme' enabling students to "engage with a diverse range of projects and participants incorporating areas, such as working with the homeless community, women and girls, mental health and well-being, disability, youth and many more. To work with such a range of participants across a broad spectrum of projects offers students a variety of challenges and problems which are 'real world' and, as such, require real solutions" (Bourne). 


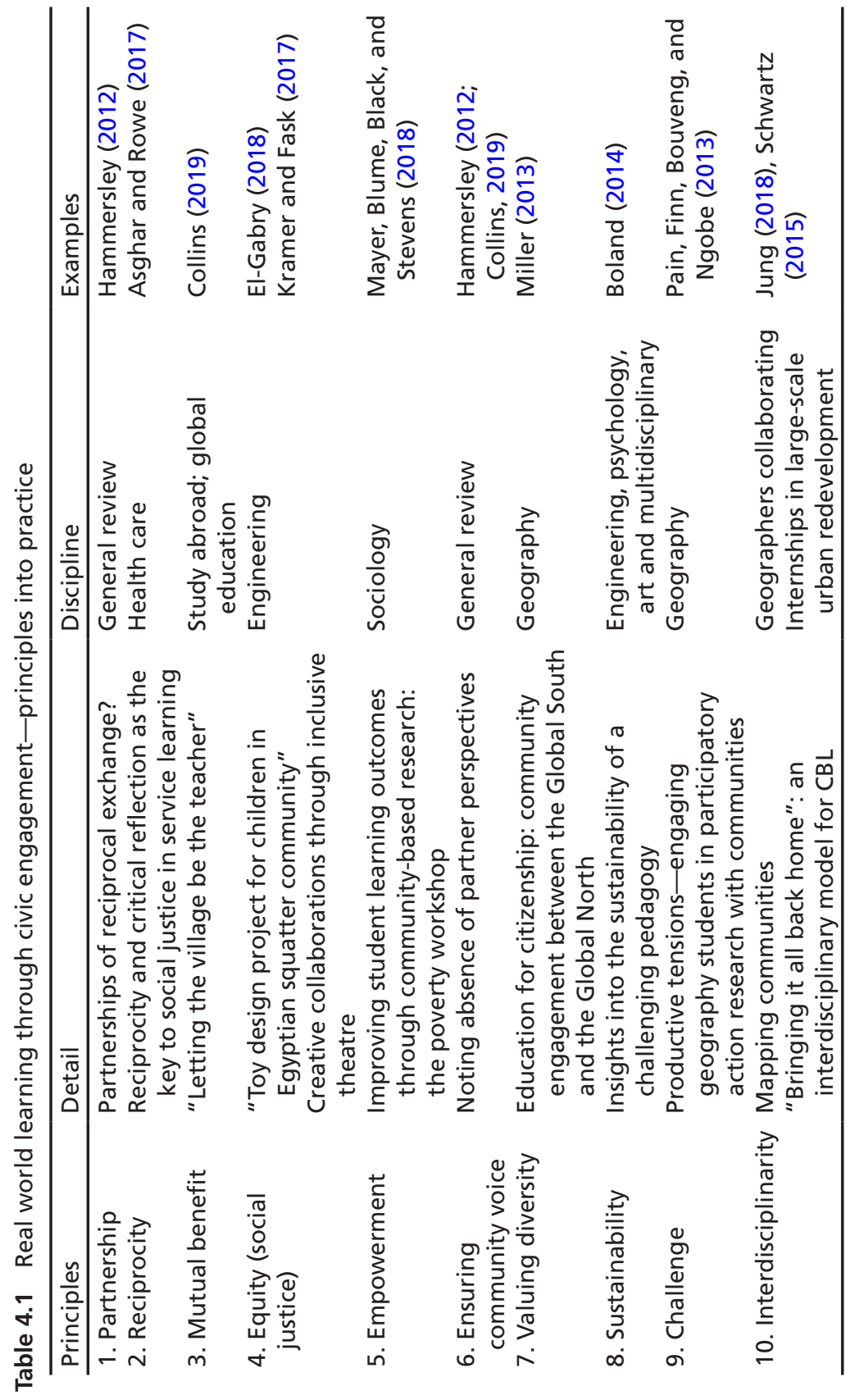


4 Real World Learning Through Civic Engagement: Principles...

Table 4.2 Real world learning through civic engagement-four case studies

\begin{tabular}{|c|c|}
\hline Title & Author \\
\hline $\begin{array}{l}\text { International Practicum Pilot: } \\
\text { Limerick Inside Out }\end{array}$ & $\begin{array}{l}\text { Tracey Gleeson, Kerstin Mey and Anne } \\
\text { Warren-Perkinson, University of } \\
\text { Limerick }\end{array}$ \\
\hline $\begin{array}{l}\text { The Solent Football Leadership } \\
\text { Programme (SFLP) }\end{array}$ & Tracey Bourne, Solent University \\
\hline $\begin{array}{l}\text { The Community Innovation } \\
\text { Programme, Healthy Living } \\
\text { Project }\end{array}$ & Amy E. King, Solent University \\
\hline $\begin{array}{l}\text { Making Change Happen-Civic } \\
\text { Engagement in Practice }\end{array}$ & $\begin{array}{l}\text { Linda Cooper and Duncan Reavey, } \\
\text { University of Chichester }\end{array}$ \\
\hline
\end{tabular}

The principle of interdisciplinarity features strongly in the case studies from the universities of Limerick and Chichester with the former stating, "Exchange, sharing and collaborations with communities in the city and the region have been developed in and across disciplines, from health and sports to law and languages, from entrepreneurship to the sciences and the creative and performing arts" (Gleeson et al.). The 'Making Change Happen-Civic Engagement in Practice' case study from the University of Chichester states, "Projects only work if students learn how to work with many different kinds of people and acknowledge that success comes from working across disciplines" (Cooper and Reavey).

The case studies illustrate how the principle of challenge can empower students and community stakeholders as agents of change. For example, the University of Chichester case study stresses that projects "required students to come up with a creative solution to make change happen" (ibid.). Students engaged in the International Practicum Pilot 'Limerick Inside Out' "felt that the direct interaction with community representatives and the teamwork were most empowering" (Gleeson et al.). In the Solent University 'Healthy Living Project', "Collaboration with the women was critical in shaping the project further and provided the participants and students with a feeling of shared ownership and empowerment" (King).

The principle of ensuring community voice features across the four case studies with the University of Chichester example emphasising "From the start, students listen to the broader community voice so they begin to 
understand diversity of views of stakeholders in the broadest sense-not just a head teacher or the CEO of a charity but children on the School Council, teachers in staff meetings, people in the neighbourhood" (Cooper and Reavey). The University of Limerick case study states, "By participating in the students' welcome session and the final public exhibition, various community partners with different interests came together in an informal and special setting to give voice to their work" (Gleeson et al.). The 'Solent Football Leadership Programme' highlights the local community "engaging with the project work and voicing their needs, not just for developing football itself, but also for developing communities and community cohesion via the vehicle of football" (Bourne). This illustrates the potential of community-based learning to cascade benefits beyond the direct initial focus of the initiative-important for its reach and legacy.

All of the case studies are characterised by principles of reciprocity and mutual benefit, for example, the 'Healthy Living Project' from Solent University "provides the students with a platform to put into practice classroom taught theories and skills as well as providing the community with a sustainable initiative addressing a health or social need" (King).

Collectively the case studies demonstrate diverse ways of developing and implementing real world learning through civic engagement. They express how students, faculty and community members effectively undertake challenging initiatives across a range of disciplines. They show how students forge deep connections between theories learned in lectures and seminars with the 'real world' beyond. They demonstrate how strong sustainable links are created between university and community and illustrate practical ways of promoting and inculcating principles of equity and social justice through real world learning. Importantly these four case studies clearly show how principles of real world learning through civic engagement can be applied in practice.

For real world learning through civic engagement initiatives to be similarly effective and sustainable, it is vital they be strategically led, encouraged and appropriately supported by their institutions; energy and commitment of students, staff and communities are necessary but insufficient. We turn our attention to this matter in the following section. 


\section{Institutions Must Do Their Own Real World Learning: Leadership and Strategy}

\section{Linking Institutional Imperatives}

Writing the university civic engagement mission statement is the easy bit; the difficulty for institutions is to create a holistic ethos of critical reflection and open dialogue which promotes and supports real world student learning through civic partnerships. The challenge is to create learning opportunities that benefit and empower students, communities and faculty. Excellent opportunities exist to capitalise on synergies between different strategic imperatives: developing professional and personal graduate attributes_-employability, learning for sustainability and active citizenship. This can be achieved by integrating agendas for critical civic engagement with those of ESD and citizenship education-linking drivers for regional, national and international development.

Implementing real world learning through civic engagement demands commitment and action on multiple fronts. Our international scoping survey showed that whilst increasing numbers of institutions had been committing to student learning through community engagement, there was little alignment between this commitment and institutional processes to support it (McEwen \& Mason O’Connor, 2013). Other findings were the following: wide variability in recognition and reward ranging from well-established promotion processes to absence of any form of recognition; frequent lack of accounting for community engagement as part of workload allocation; few coherent processes of supportive staff and educational development, and inflexible institutional procedures which curb staff enthusiasm.

\section{Distributed Leadership in Action}

Whilst the literature on leadership of university civic engagement points almost universally to the importance of 'distributed leadership', it acknowledges there is no optimal approach; institutions need to work out for themselves how leadership is distributed, recognising that "the 
infrastructure for engagement does not necessarily align with the institutional hierarchy" (Liang \& Sandmann, 2015, p. 37). Leadership must take place at all levels across the institution to build and support innovative creative institutional cultures. This is particularly challenging when academics are arguing that forces of marketisation generate "continuous pressures to standardize, conform, obey and duplicate in order to be 'transparent' to measurement" (Lesnik-Oberstein et al., 2015). Leaders need to challenge institutional boundaries: "entrenched interests of disciplines, academic departments, and traditional epistemology militate against the full emergence of community engaged scholarship" (Giles, 2016, p. 194). Relaxing the 'disciplinary grip' (Ivison, 2018) requires considerable leadership skill and courage. Establishing porous boundaries enables and encourages networking and innovation across and beyond the institution and "supports two-way flow of information, people and resources ... which integrate and connect universities physically, digitally and intellectually to society" (Wilson, Manners, \& Duncan, 2014, p. 9). It advances and fosters claims by communities within and beyond its parameters that the institution is 'our university'.

Transformative pedagogies and key principles are the hallmarks of real world learning through civic engagement. Leading change in this direction is challenging; transformative learning, as previously indicated, can be "troublesome" (Perkins, 1999), a risky endeavour with uncertain outcomes. Leadership is required to develop courses and university quality assurance processes agile enough to foster and accredit learning that takes place in contexts where outcomes are unpredictable and where new ones might emerge. In our work on developing community engagement (Mason O'Connor \& McEwen, 2012, p. 12), we devised a set of questions to assure quality of accredited community-based learning: for example, "How are 'unanticipated learning outcomes' to be recognised and assessed?"; "How is mutual benefit and reciprocity for all stakeholders maintained?”

Importantly, leadership and strategy have to ensure support and recognition for the three key stakeholders engaged in real world learning through civic engagement: students, community and faculty. 


\section{Support and Recognition for Students}

Through critical community-based learning, students can acquire a variety of graduate attributes for employability, sustainable development and active citizenship. A recent publication on graduate attributes and higher education (Normand \& Anderson, 2017) reinforces the view that graduate attributes sought by employers extend well beyond the possession of disciplinary knowledge. In rapidly changing social and economic contexts, a range of interpersonal skills and abilities are vital, such as selfawareness, resilience, adaptability and empathy. Real world learning through civic engagement can be a key means of developing these attributes (Mason O'Connor, Lynch, \& Owen, 2011). It must be emphasised, however, that students beginning, undertaking and concluding civic engagement initiatives require appropriate support and encouragement not only for the 'academic' element of their work but, crucially, for the affective element where long-held understandings and beliefs may be challenged and the outcome of the initiative is uncertain. Importantly, students should be supported and assessed on the development of their reflective learning throughout the process of civic engagement rather than the 'success' or otherwise of the initiative.

\section{Support and Recognition for Community}

Communities are not extra-mural laboratories for university use. Community learning has to be supported and evaluated on a par with student learning. As individuals and/or groups, community members may need support for participation in civic engagement initiatives particularly those communities who are 'under-served'. This could, for example, include funds for any costs incurred engaging with university students, such as the use of reciprocal engagement spaces. As Collins (2019) proposes, communities need to be compensated justly for their work. For radical civic engagement to be facilitated, it is necessary to ensure that "equity, justice, and an appreciation of diverse value systems 
and perspectives are included in the development of civic actors, civic learning, and shared projects of social change in local communities" (Hicks Petersen, 2015, p. 17).

\section{Support and Recognition for Faculty}

Based on their research and work with a wide range of institutions in the UK, Manners and Duncan (2018) conclude, "without an explicit focus on developing supportive organisational cultures, staff feel discouraged from engaging externally; and the quality and effectiveness of that engagement can be compromised" (Manners \& Duncan, 2018, p. 3).

In our work on building staff capacity for university-community engagement, we identified key staff attributes, skills and attitudes and dispositions which contribute to effective university-community engagement. Attitudes and dispositions include "commitment to social justice" and "willingness to engage and take risks"; skills include "design for mutual benefit" and "interdisciplinary working"; knowledge included "ethical practice" and "pedagogies of active reflective learning" (Mason O'Connor \& McEwen, 2012, p. 14). Some skills needed by Faculty for CBL link well to the research skills in community-based participatory research (Durham Community Research Team, 2011). These take greater account of issues of power, rights and responsibilities and roles of all stakeholders, based on respect for, and partnership with, community members.

As well as requiring support, civic engagement has to be incentivised, recognised and valued (McEwen \& Mason O'Connor, 2013). Boland's research showed engagement work was seen by academics as something they elected to do. "A corollary of the elective nature of this work is that civic engagement is not generally regarded as part of the academic role" (Boland, 2014, p. 190). Recruitment, promotion and appraisal systems need to recognise this work.

We conclude our discussion on leadership and strategy by referring to an international meeting of vice-chancellors in Melbourne. Acknowledging staff reluctance to be involved in civic engagement work because university rankings systems foreground research, the vice-chancellor of 
Queensland University issued a challenge: "many of these global rankings are based on what we can readily measure, rather than what we have to learn to measure" (Havergal, 2017).

\section{Conclusion}

We have shown in this chapter that real world learning through civic engagement encompasses a range of rationales, pedagogies and approaches. It has developed from a paradigm of expanding learning opportunities for students through volunteering to one in which students are challenged to develop as empowered active citizens. Students are prepared for future uncertainties and opportunities, learning in partnership with others to bring about positive change. Underpinning this paradigm are key principles. Exploring, developing and applying these principles through effective leadership at all levels can enable universities to connect with communities locally and globally, providing institutional aspirational rhetoric with rich 'real world' realities.

\section{References}

Advisory Group on Citizenship. (1998). Education for citizenship and the teaching of democracy in schools [Crick Report]. Qualifications and Curriculum Authority. Retrieved from https://www.teachingcitizenship.org.uk/sites/ teachingcitizenship.org.uk/files/6123_crick_report_1998_0.pdf

Asghar, M., \& Rowe, N. (2017). Reciprocity and critical reflection as the key to social justice in service learning: A case study. Innovations in Education and Teaching International, 54(2), 117-125. https://doi.org/10.1080/1470329 7.2016.1273788

Blouin, D. D., \& Perry, E. M. (2009). Whom does service learning really serve? Perspectives on service learning. Teaching Sociology, 37(2), 120-135.

Boland, J. A. (2014). Orientations to civic engagement: Insights into the sustainability of a challenging pedagogy. Studies in Higher Education, 39(1), 180-195. https://doi.org/10.1080/03075079.2011.648177 
Boyer, E. (1996). The scholarship of engagement. Journal of Public Service and Outreach, 1(1), 11-20.

Brabant, M., \& Braid, D. (2009). The devil is in the details: Defining civic engagement. Journal of Higher Education Outreach and Engagement, 13(2), 59-87.

Brabner, R. (2019). The creation of a civic university agreement was the principle (sic) recommendation of the UPP Foundation Civic University Commission. Retrieved from https://upp-foundation.org/over-50-universities-pledgecomchellment-to-local-communities-through-civic-university-agreement/

Brown University. Retrieved from https://www.brown.edu/swearer/carnegie

Collins, L. (2019). Letting the village be the teacher: A look at communitybased learning in Northern Thailand. Teaching in Higher Education, 24(5), 694-708. https://doi.org/10.1080/13562517.2019.1579708

Delucchi, M., \& Smith, W. L. (1997). Satisfied customers versus pedagogic responsibility: Further thoughts on student consumerism. Teaching Sociology, 25(4), 336-337.

Durham Community Research Team. (2011). Community-based participatory research: Ethical challenges. Retrieved from http://www.ahrc.ac.uk/documents/project-reports-and-reviews/connected-communities/communitybased-participatory-research-ethical-challenges/

El-Gabry, L. (2018). Case study on community-based learning: Toy design project for children in Egyptian squatter community. European Journal of Engineering Education, 43(6), 879-894. https://doi.org/10.1080/0304379 7.2018.1451492

Fallace, T. D. (2016). John Dewey's visions(s) for interdisciplinary social studies. Social Studies Research and Practice, 11(1), 177-189.

Fink, L. D. (2003). Creating significant learning experiences: An integrated approach to designing college courses. San Francisco, CA: Jossey-Bass Higher and Adult Education.

Freire, P. (2005). Pedagogy of the oppressed (30th Anniversary ed., M. B. Ramos, Trans.). New York: Continuum.

Fung, D. (2016). Engaging students with research through a connected curriculum: An innovative approach. CUR Quarterly, 7(2), 30-35. Retrieved from http://www.cur.org/assets/1/23/win16-Article5.pdf

Gibbons, M. (2000). Mode 2 society and the emergence of context-sensitive science. Science and Public Policy, 27(3), 159-163. 
Giles, D. E. (2016). The emergence of engaged scholarship: Seven additional years of evolution. Journal of higher Education Outreach and Engagement, 20(1), 193-195. ISSN: 1534-6104, eISSN: 2164-8212.

Goddard, J., \& Kempton, L. (n.d.). The civic university: Universities in the leadership of management and place. Retrieved from https://warwick.ac.uk/research/ warwickcommission/chancellorscommission/report/appendices/curds_warwick_report_final.pdf

GuildHE/National Union of Students. (2016). Active citizenship: The role of higher education. GuildHE. Retrieved from: https://guildhe.ac.uk/wp-content/uploads/2016/11/6710-Guild-HE-Active-Citizenship-Report-44pp.pdf GUNI (Global University Network for Innovation). (2013). Higher Education in the World (5). Knowledge, engagement and higher education: Contributing to social change (B. Hall \& R. Tandon, Guest Eds.). London: Palgrave Macmillan. Hall, B., Lall, N., \& Heng Chan, L. (n.d.). Knowledge for the world we want: The emergence of the Global Alliance for Community Engaged Research (GACER). Retrieved from: http://www.guninetwork.org/articles/knowledge-worldwe-want-emergence-global-alliance-community-engaged-research-gacer

Hammersley, L. (2012). Community-based service-learning: Partnerships of reciprocal exchange? Special Issue: Work Integrated Learning - Investing in the Future. Papers from the Australian Collaborative Education Network Annual Conference 2012.

Havergal, C. (2017, September 24). Research focus of global rankings a 'barrier' to community engagement. Times Higher Education.

Hicks Petersen, T. (2015). Reviving and revising the civic mission: A radical reimagining of "civic engagement". Metropolitan Universities: An International Forum, 25(3), 17-30.

Hill, F. (2015). Taking stock: A review of university public engagement activity. Final Report. Bristol: National Co-ordinating Centre for Public Engagement. Ivison, D. (2018, April 12). Disciplines must relax if the big challenges are to be met. Times Higher Education.

Jung, J.-K. (2018). Mapping communities: Geographic and interdisciplinary community-based learning and research. The Professional Geographer, 70(2), 311-318. https://doi.org/10.1080/00330124.2017.1366787

Kerslake, R. W. (2019). Foreword to Truly Civic: Strengthening the Connections Between Universities and their Place. The Final Report of the UPP Foundation Civic University Commission, UK. 
Kramer, L. A., \& Fask, J. F. (2017). Creative collaborations through inclusive theatre and community based learning: Students in transition. Palgrave Macmillan.

Lesnik-Oberstein, K., et al. (2015, July 6). Let UK universities do what they do best - teaching and research. Letter to The Guardian signed by over 100 academic staff. Retrieved from: https://www.theguardian.com/education/2015/ jul/06/let-uk-universities-do-what-they-do-best-teaching-and-research

Liang, J. G., \& Sandmann, L. R. (2015). Leadership for community engagement: A distributed perspective. Journal of Higher Education and Outreach and Engagement, 19(1), 35-62. ISSN: 1534-6104.

Lotz-Sisitka, H., Wals, A. E., Kronlid, D., \& McGarry, D. (2015). Transformative, transgressive social learning: Rethinking higher education pedagogy in times of systemic global dysfunction. Current Opinion in Environmental Sustainability, 16, 73-80. https://doi.org/10.1016/j.cosust.2015.07.018

Manners, P., \& Duncan, S. (2018). NCCPE response to UPP foundation civic university commission. Bristol: National Co-ordinating Centre for Public Engagement. Retrieved from https:/www.publicengagement.ac.uk/sites/ default/files/publication/nccpe_response_to_upp_commission_300718.pdf

Mason O'Connor, K., Lynch, K., \& Owen, D. (2011). Student-community engagement and the development of graduate attributes. Education and Training, 53(2/3), 100-115. https://doi.org/10.1108/00400911111115654

Mason O'Connor, K., \& McEwen, L. J. (2012). Developing community engagement. SEDA Special 32. London: Staff and Educational Development Association.

Mason O’Connor, K., McEwen, L. J., Owen, D., Lynch, K., \& Hill, S. (2011). Literature review. Embedding community engagement in the curriculum: An example of university-public engagement. Bristol: National Co-ordinating Centre for Public Engagement and University of Gloucestershire.

Mayer, B., Blume, A., Black, C., \& Stevens, S. (2018). Improving student learning outcomes through community-based research: The poverty workshop. Teaching Sociology, 47(2), 135-147. https://doi.org/10.117 7/0092055X18818251

McEwen, L. J., \& Mason O'Connor, K. (2013). Communiversity: Building staff faculty capacity for university-public/community engagement. Report. Retrieved from www.uwe.ac.uk/repository

McEwen, L. J., Strachan, G., \& Lynch, K. (2011). "Shock and awe" or "reflection and change": How can research into transformative learning inform 
pedagogic practice in higher education? Learning and Teaching in Higher Education, 5, 34-55.

Meyer, J. H. F., \& Land, R. (2005). Threshold concepts and troublesome knowledge (2): Epistemological considerations and a conceptual framework for teaching and learning. Higher Education, 49(3), 373-388.

Mezirow, J. (1978). Perspective transformation. Adult Education Quarterly, $28,100-110$.

Mezirow, J. (1991). Transformative dimensions of adult learning. San Francisco, CA: Jossey-Bass.

Mezirow, J. (2000). Learning to think like an adult: Core concepts of transformation theory. In J. Mezirow \& Associates (Ed.), Learning as transformation: Critical perspectives on a theory in progress (pp. 3-34). San Francisco, CA: Jossey-Bass.

Mezirow, J. (2003). Transformative learning as discourse. Journal of Transformative Education, 1(1), 58-63.

Miller, G. (2013). Education for citizenship: Community engagement between the Global South and the Global North. Journal of Geography in Higher Education, 37(1), 44-58. https://doi.org/10.1080/03098265.2012.757299

Mitchell, T. D. (2008). Traditional versus critical service learning: Engaging the literature to differentiate two models. Michigan Journal of Community ServiceLearning, 14(2), 50-65.

Normand, C., \& Anderson, L. (Eds.). (2017). Graduate attributes in higher education: Attitudes on attributes across the disciplines. London: Routledge.

O'Mahoney, C., Burns, K., \& McDonell, C. (n.d.). Community-based research: An introductory guide for higher education staff. Campus Engage. Retrieved from https://www.livingknowledge.org/fileadmin/Dateien-Living-Knowledge/ Dokumente_Dateien/Toolbox/Community-Based_Research_WEB_1_.pdf

Office for Students. (2019). What if the TEF? Retrieved from https://www. officeforstudents.org.uk/advice-and-guidance/teaching/what-is-the-tef/

Pain, E., Finn, M., Bouveng, R., \& Ngobe, G. (2013). Productive tensionsEngaging geography students in participatory action research with communities. Journal of Geography in Higher Education, 37(1), 28-43. https://doi. org/10.1080/03098265.2012.696594

Perkins, D. (1999). The many faces of constructivism. Educational Leadership, 57(3), 6-11. 
Sandmann, L. R. (2008). Conceptualization of the scholarship of engagement in higher education: A strategic review 1996-2006. Journal of Higher Education and Outreach and Engagement, 12(1), 91-104.

Schwartz, E. (2015). "Bringing it all back home": An interdisciplinary model for community-based learning. Journal of College \& Character, 16(1), 53-61. https://doi.org/10.1080/2194587X.2014.992910

Stoecker, R. (2016). Liberating service learning and the rest of higher education civic engagement. Philadelphia, PA: Temple University Press.

Talloires Network. (2005). Talloires declaration on the civic roles and social responsibilities of higher education. Retrieved from https://talloiresnetwork.tufts. edu/who-we-are/talloires-declaration/

Tandon, R., Hall, B., Lepore, W., \& Singh, W. (2016). Training the next generation of community based researchers: A guide for trainers. PRIA (Society for Participatory Research in Asia), India, \& University of Victoria, Canada.

UK Research Innovation. (n.d.). REF Impact. Retrieved from https://re.ukri. $\mathrm{org} /$ research/ref-impact/

UNESCO. (2009). 2009 World conference on higher education: The new dynamics of higher education and research for societal change. Paris: United Nations Educational, Scientific and Cultural Organization.

UNESCO. (2014). UNESCO roadmap for implementing the global action programme on education for sustainable development. Paris: United Nations Educational, Scientific and Cultural Organization.

UNESCO. (2018). Issues and trends in education for sustainable development. Paris: United Nations Educational, Scientific and Cultural Organization.

Wasner, V. (2016). Critical service learning: A participatory pedagogical approach to global citizenship and international mindedness. Journal of Research in International Education, 15(3), 238-252. https://doi.org/10.1177/ 1475240916669026

Watson, D., Hollister, R. M., Stroud, S. E., \& Babcock, E. (2011). The engaged university: International perspectives on civic engagement. Taylor and Francis Group: Routledge.

Weinberg, J., \& Flinders, M. (2018). Learning for democracy: The politics and practice of citizenship education. British Educational Research Journal, 44(4), 573-592. https://doi.org/10.1002/berj.3446

Wells, P. J. (2017). The role of higher education institutions today: Balancing the global with the local. GUNI HEIW Report. Retrieved from http://www.guninetwork.org/files/download_full_report.pdf 
Wilson, C., Manners, P., \& Duncan, S. (2014). Building an engaged future for UK higher education. Full report from the engaged futures consultation. Bristol: National Co-ordinating Centre for Public Engagement.

Wood, B. E., Taylor, R., Atkins, R., \& Johnston, M. (2018). Pedagogies for active citizenship: Learning through affective and cognitive domains for deeper democratic engagement. Teaching and Teacher Education, 75, 259-267. https://doi.org/10.1016/j.tate.2018.07.007

Open Access This chapter is licensed under the terms of the Creative Commons Attribution 4.0 International License (http://creativecommons.org/licenses/ by/4.0/), which permits use, sharing, adaptation, distribution and reproduction in any medium or format, as long as you give appropriate credit to the original author(s) and the source, provide a link to the Creative Commons licence and indicate if changes were made.

The images or other third party material in this chapter are included in the chapter's Creative Commons licence, unless indicated otherwise in a credit line to the material. If material is not included in the chapter's Creative Commons licence and your intended use is not permitted by statutory regulation or exceeds the permitted use, you will need to obtain permission directly from the copyright holder.

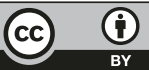

